University of Florida Levin College of Law

UF Law Scholarship Repository

UF Law Faculty Publications

Faculty Scholarship

$1-2007$

\title{
Trademark Law and Status Signaling: Tattoos for the Privileged
}

Jeffrey L. Harrison

University of Florida Levin College of Law, harrisonj@law.ufl.edu

Follow this and additional works at: https://scholarship.law.ufl.edu/facultypub

Part of the Consumer Protection Law Commons, and the Intellectual Property Law Commons

\section{Recommended Citation}

Jeffrey L. Harrison, Trademark Law and Status Signaling: Tattoos for the Privileged, 59 Fla. L. Rev. 195 (2007), available at http://scholarship.law.ufl.edu/facultypub/180

This Article is brought to you for free and open access by the Faculty Scholarship at UF Law Scholarship Repository. It has been accepted for inclusion in UF Law Faculty Publications by an authorized administrator of UF Law Scholarship Repository. For more information, please contact kaleita@law.ufl.edu. 
TRADEMARK LAW AND STATUS SIGNALING: TATTOOS FOR THE PRIVILEGED

\author{
Jeffrey L. Harrison*
}

I. INTRODUCTION ........................ 195

II. TRAdEMARK, StAtus Symbols, AND CONFUSION . . . . . . 198

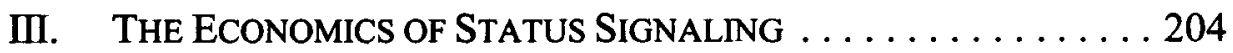
A. Veblen Effects ......................... 205

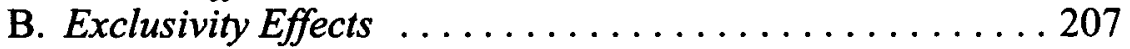

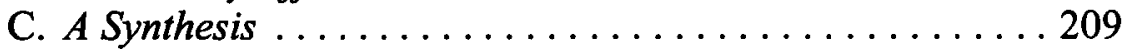

IV. The Efficiency of Status Signaling $\ldots \ldots \ldots \ldots \ldots 210$

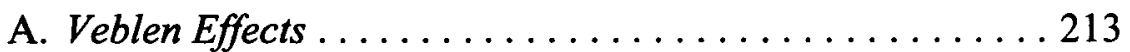

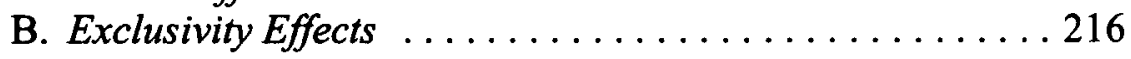

V. The Morality of Status Signaling $\ldots \ldots \ldots \ldots \ldots 220$

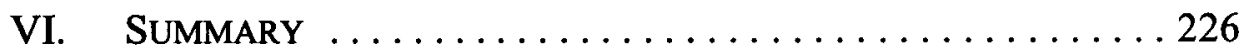

\title{
I. INTRODUCTION
}

The motivations for buying a good or service are highly complex. At the most basic level, people buy goods because of what the goods do or because of the aesthetic elements they embody. More technically, buyers derive utility from the "functional" quality ${ }^{1}$ of these goods. Another motivation relates to what the goods "say" about the buyer. Here, the good is a signaling device. ${ }^{2}$ Signaling is not new, of course, and can indicate anything from social class to political leanings. The means can include anything that is displayed, driven, sat on, worn, or even eaten. Current

* Stephen C. O'Connell Chair, University of Florida College of Law. I appreciate the comments of Sarah Wilson, McCabe Harrison, and Jules Theeues. Special thanks to Deb Cupples whose research on the Hermès "Kelly Bag" led to this project.

1. "Functional" in this sense is defined broadly to include not just what a product does physically, but also the utility it creates by virtue of its appearance.

2. These are also referred to as "positional" goods because they denote a position in the status ranking. See Robert H. Frank, The Demand for Unobservable and Other Nonpositional Goods, 75 AM. ECON. REV. 101, 101 (1985); Norman J. Ireland, On Limiting the Market for Status Signals, 53 J. PUB. ECON. 91 , 91 (1994). 
popular forms include T-shirts, bumper stickers, tattoos, and piercings. ${ }^{3}$ In a great many of these cases, buyers and sellers operate in markets that are unassisted by government intervention. That is, the markets for signaling devices exist without government subsidization. The markets for some signaling, however, depend on government involvement to operate successfully. These tend to be markets for products that signify wealth and status. Government subsidization comes in the form of trademark law.

The signaling phenomenon can be understood by thinking of the following hypothetical experiment. Suppose a buyer faces a choice between two polo shirts. There is no doubt in the buyer's mind that the shirts are identical in terms of fabric, comfort, and durability. One shirt has no trademark on it, while the other bears the mark of "Etro," a high-end Italian design house. Some buyers will pay a premium for the Etro mark. One way to understand this consumer behavior is to say that the price paid in part compensates for the function of the product-color, fabric, durability - and the remainder of the price is accounted for by nonfunctional factors. ${ }^{4}$ In this case, the non-functional factor is the fact that the logo communicates a message to others seeing the shirt. ${ }^{5}$

This Essay addresses the issue of whether it should be public policy to subsidize this type of person-to-person status signaling. This question falls within the general category of issues related to the production and dissemination of information. As a general matter, it appears that markets, if left unregulated, do not produce efficient levels of information. ${ }^{6}$ This is in large measure due to free-riding problems that prevent those producing information from limiting its use to those who pay for it. Free-riding, of course, is the underlying rationale for American intellectual property law.

3. See generally Joseph Cockman, Running From the Runway: Trade Dress Protection in an Age of Lifestyle Marketing, 89 lowA L. REV. 671, $672-73$ (2004).

4. There is, for some, a possibly fine distinction to be made here. To the extent the purchaser simply enjoys the Etro logo-thinks it is cute or funny-the impact is functional. Thus, even payment for the logo can be part of the functional element.

5. Goods of this nature are often referred to as "Veblen goods." This is a reference to Thornstein Veblen, to whom the term "conspicuous consumption" is attributed. For an empirical examination of signaling, see Angela Chao \& Juliet B. Schor, Empirical Tests of Status Consumption: Evidence from Women's Cosmetics, 19 J. ECON.PSYCHOL. 107, 109 (1998). See also Laurie Simon Bagwell \& B. Douglas Bernheim, Veblen Effects in a Theory of Conspicuous Consumption, 86 AM. ECON. REV. 349 (1996) (examining situations where "Veblen effects" arise from the desire to gain social status by conspicuous consumption to signal wealth); Robert $\mathrm{L}$. Basmann et al., A Note on Measuring Veblen's Theory of Conspicuous Consumption, 70 REV. ECON. \& STAT. 531 (1988) (testing Veblen's theory of conspicuous consumption).

6. Here, inefficiency means that a good or service-in this case information-is not produced even though the benefits exceed the costs of production. See generally Joseph E. Stiglitz, The Contributions of the Economics of Information to Twentieth Century Economics, 115 Q.J. ECON. 1441 (2000) (arguing that the economics of information has profoundly affected modern economics). 
A composer or inventor is protected from free-riding as a means of increasing the incentive to be creative. When it comes to trademark, the focus is less on the producer and more on consumers. The idea is to lower search costs for consumers by reducing the confusion that would result if the trademark identified with one producer or product were then used by another producer. Still, the underlying problem is one of free-riding. A party infringing on the trademark of another free-rides on the trademark owner's investment in ensuring that labels ranging from McDonald's to Rolex actually stand for specific qualities. ${ }^{7}$

Given the focus of trademark on consumers' confusion and search costs, it may surprise some to learn that courts have generally accepted the idea that one role of trademark law is to facilitate status signaling ${ }^{8}$-signaling not about the product or service but about the person purchasing that product or service. Nevertheless, the economics of selling status signaling would, on its face, seem to be no different from the economics of selling other information products. For example, the manufacturer of Etro shirts is selling not just the material and aesthetic qualities of the shirt, but also the right to display the Etro logo. If other producers free-ride by selling counterfeit Etro shirts, they reduce the incentive for Etro to develop and invest in new means for this form of signaling.

The fact that the economic analysis seems to be the same for status signaling as it is for more typical trademark purposes does not mean that a policy of subsidization is easily defended. ${ }^{9}$ That defense would have to be based on a belief that, without what amounts to public subsidization, there would be too little information disseminated related to relative status. This belief, in turn, would have to have some underlying economic or moral basis that status signaling is ultimately beneficial, in the case of economics, or a "right," in the case of a moral or "rights"-based rationale.

An economist attempting to justify a policy or law must demonstrate that the policy will lead to outcomes that are either Pareto superior, utility increasing/maximizing, or wealth increasing/maximizing. These are the three concepts that economists typically use to analyze well-being, with the wealth-maximization standard being the most common. A moral claim for status signal subsidization would be based on a rationale other than

7. It is important to note that some trademarks would also be subject to copyright protection. The focus here is on the trademark question only.

8. For a history of the development of this rationale, see David M. Tichane, The Maturing Trademark Doctrine of Post-Sales Confusion, 85 TRADEMARK REP. 399 (1995).

9. Judge Alex Kozinski offers some brief comments on these matters. See generally Alex Kozinski, Trademarks Unplugged, 68 N.Y.U. L. REV. 960 (1993) (reconsidering the legal status of trademarks). 
creating incentives, ${ }^{10}$ but that does not mean there are no trade-offs involved. A moral, rights-based justification could call into question other rights that must be weighed against those supporting a policy of protecting status symbols.

Part II of this Essay provides a brief overview of the status-symbolprotecting elements of trademark law. Part III describes the economics of status signaling. Paretian and wealth-maximization standards of efficiency will be used as measures of economic welfare to avoid the well-known problems of assessing any public policy from a strict utilitarian perspective." The analysis distinguishes between so-called "Veblen effects" and snob effects. Part III concludes that there exists no reasonable argument that the market produces suboptimal levels of status signaling. Part IV considers rights-based arguments for subsidized status signaling. It examines both Rawlsian ${ }^{12}$ and Lockean ${ }^{13}$ rationales for subsidization of status signaling and concludes that there is no philosophical support for public subsidization of status signaling.

\section{TRADEMARK, STATUS SyMbOLS, AND CONFUSION}

The central function of trademark law is to lower search costs for buyers. ${ }^{14}$ The means of achieving this end is to permit a seller to have exclusive rights to a trademark that identifies the source of a product and, consequently, certain characteristics. ${ }^{15}$ Thus, if a product bears the mark "Hermès," "McDonald's," "Ralph Lauren," or "Rolex," the buyer knows certain information without further inquiry. The exclusive use of a trademark is generally designed to avoid confusion among potential purchasers.

The problem is that confusion can be, well, a confusing concept. ${ }^{16}$

10. Id. at 966-67.

11. See generally RoBert Nozick, ANARChY, StATE, AND UtOPIA 39-41 (1974); J. J. C. SMART \& BERNARD WILLIAMS, UTLITARIANISM: FOR AND AGAINST 77-150 (1973).

12. See infra notes $100-03$ and accompanying text.

13. See infra notes $104-20$ and accompanying text.

14. For the most thorough economic analysis, see generally William M. Landes \& Richard A. Posner, The Economics of Trademark Law, 78 TRADEMARK REP. 267 (1988). See also Robert G. Bone, Enforcement Costs and Trademark Puzzles, 90 VA. L. REV. 2099, $2105-07$ (2004).

15. See generally Barton Beebe, Search and Persuasion in Trademark Law, $103 \mathrm{MICH}$. L. REV. 2020 (2005) (explaining distinctiveness); Jessica Litman, Breakfast with Batman: The Public Interest in the Advertising Age, 108 Y ALE L.J. 1717 (1999) (analyzing the effects of legal protection of trade symbols).

16. See generally Michael J. Allen, The Scope of Confusion Actionable Under Federal Trademark Law: Who Must be Confused and When?, 26 WAKE FOREST L. REV. 321 (1991) (discussing "the difficult task of defining the scope of likely confusion prohibited by federal trademark law"); Tichane, supra note 8 (tracing the development of and various issues surrounding the post-sale confusion doctrine). 
Three aspects of confusion must be considered. Examining them provides a context for the analysis that follows. The first is the time of the confusion. Does the confusion occur before the purchase or could the confusion occur after the particular item has been purchased? Second, is it the confusion of the purchaser or some other party? In the context of this Essay, can the confusion be that of a non-purchaser who may see an item and be confused about whether it is a genuine Kelly Bag, Rolex watch, or Etro shirt?

Finally, and most importantly, what is the consequence of the confusion? On one hand, suppose a third party who is potentially in the market for an expensive watch sees your watch that is falsely marked "Rolex." He believes it to be the genuine article and also notes that it appears to be cheaply made and is inaccurate. This has an impact on the manufacturer of Rolex watches. In effect, those producing the copies interfere with effective communication between the manufacturer and potential customers. This is, of course, the simple case, and the one that may justify public involvement. ${ }^{17}$

There are, however, other possibilities. Suppose, again, the third party sees your $\$ 30$ imitation Rolex watch and believes it is real, and it appears to be functioning perfectly. He or she may not know that $\$ 30$ "Rolexes" are available. Although the observer of the watch will be wrong about the source of the watch, it is difficult to see this confusion as having any direct impact on what one believes when one sees a watch bearing the name Rolex. On the other hand, it is possible that an inflated number of watches that seem to be Rolexes will affect the observer's opinion of you. The Rolex name will fail as a means for you to signal your exclusivity, independent of the functional qualities of the watch.

If it is commonly known that there are fake Rolexes in the market, the signaling problem becomes more severe. The observer now will not know whether your Rolex is real or fake. Are you just a sleazy pretender wearing a fake or are you the "real" thing? Obviously, Rolex becomes less effective as a status symbol, and the owner of a genuine Rolex is harmed because the signal, or the information he or she sought to convey, is distorted. This might be analogous to the bearer of a tattoo being required to wear an article of clothing that covers it. In addition, the makers of the signal embodied in a genuine Rolex watch will find that the signaling quality of the watch is devalued. This hurts the sales of Rolex watches-or at least sales of the name "Rolex"- to the extent Rolexes are purchased as signaling devices. ${ }^{18}$

17. Whether intervention is warranted depends on weighing the costs and benefits.

18. Judge Kozinski has argued that this can be viewed as a moral wrong because the counterfeiters free-ride on the efforts of Rolex to build its exclusive image. See Kozinski, supra note 9 , at 967 . He does not address the issue of whether it is moral to invest in a product whose 
This Essay is about the special circumstance of the confusion taking place after a purchase in which the confused person is 'not a potential purchaser but one who is misled about the status or wealth of the person displaying the infringing mark. Interestingly, and perhaps surprisingly, this type of confusion is clearly protected by today's trademark law. Specifically, as trademark law has evolved, it has been extended to cover the after-purchase confusion of non-buyers. To this end, section 32(1) of the Lanham Act was amended in $1962 .{ }^{19}$ The original version covered instances in which an infringing use would cause confusion among "spurchasers as to the source of origin of . . goods or services." 20 The 1962 amendment removed the limitation of the Act's application to purchasers only. ${ }^{21}$

Even before 1962, however, courts recognized that confusion could affect non-purchasers. In a 1955 case, Mastercrafters Clock \& Radio Co. v. Vacheron \& Constatin-Le Coultre Watches, Inc., ${ }^{22}$ the manufacturer of the $\$ 175$ Atmos clock challenged the production of a $\$ 30$ look-alike on unfair competition grounds. ${ }^{23}$ Judge Frank authored the opinion reversing the lower court's holding of no unfair competition. ${ }^{24}$ The lower court based its decision on the lack of confusion among buyers. Because the lowerpriced clock was marked as plaintiff's (Mastercrafters) and priced accordingly, buyers knew what they were purchasing. ${ }^{25}$

Judge Frank directly invoked a right that went beyond protecting buyers from confusion:

[P]laintiff copied the design of the Atmos clock because plaintiff intended to, and did, attract purchasers who wanted a 'luxury design' clock. This goes to show at least that some customers would buy plaintiff's cheaper clock for the purpose of acquiring the prestige gained by displaying what many visitors at the customers' homes would regard as a prestigious article. Plaintiff's wrong thus consisted of the fact that such

value is derived from the subordination of others. See id. Nor does he address whether there should be a public investment in these efforts. See id.

19. Lanham Trademark Act, Pub. L. No. 87-772, § 17, 76 Stat. 769, 773-74 (1962) (codified as amended at 15 U.S.C. $\S 1114(2006))$.

20. Tichane, supra note 8 , at 401 .

21. See id. at 403.

22. 221 F.2d 464 (2d Cir. 1955).

23. Id. at 465 . The case was actually brought by Mastercrafters seeking a declaratory judgment that their clock-the less expensive one-did not unfairly compete with that of the defendant. Id.

24. Id. at 467.

25. See id. at 466 . In addition, the lower court found no evidence that the public cared about the source of the defendant's clock, and also reasoned that there was no single source of the defendant's good because more than one person lawfully distributed the Atmos clock. Id. 
a visitor would be likely to assume that the clock was an Atmos, clock. $^{26}$

The Mastercrafters case is remarkable because of the unvarnished way the issue is framed. Judge Frank does not suggest that the visitors to the house of the owner of the less expensive clock are potential purchasers who might observe the less expensive clock malfunctioning and think less of the more expensive clock. Instead, the interest protected is, in effect, conceptually separate from the clock altogether. It is a means of communicating something about the owner. If there is confusion, it is about the status of the owner of the clock.

The same sentiment is found more recently with respect to the Hermès Kelly Bag. ${ }^{27}$ After several years of evidently tolerating imitations, Hermès sued sellers of the less expensive copies. The district court focused on the confusion of potential buyers, reasoning that, even if confusion existed, there was no harm to the public. ${ }^{28}$ In effect, even if people seeing a copy were confused about whether it was a genuine Kelly Bag, that confusion would be eliminated at the point of sale. The Second Circuit reversed, employing the analysis found in Mastercrafters..$^{29}$ According to the court, "[A] loss occurs when a sophisticated buyer purchases a knockoff and

26. Id. at $\mathbf{4 6 6}$.

27. Hermès designed the Kelly handbag in the 1930s, but did not introduce it into the U.S. until approximately 1949. See Hermes Int'l v. Lederer de Paris Fifth Avenue, Inc., 50 F. Supp. 2d 212, 215 (S.D.N.Y. 1999). The bag was originally called the "Haut à Courroies." See ANNA JOHNSON, HANDBAGS: THE POWER OF THE PURSE 12 (2002); Hilary.com, Top 5 Most Extravagant Fashion Accessories, http://www.hilary.com/fashion/quickie-extravagant.html (last visited Oct. 1, 2006). Popular film stars carried the bag, including Ingrid Bergman and Marlene Dietrich. See JOHNSON, supra, at 12. Still, the bag did not reach iconic status until after 1956, when Hermès renamed it the "Kelly Bag" after Life Magazine ran a cover photo of a pregnant Princess Grace carrying the Haut à Courroies in a manner that hid the pregnancy's effect on her midriff. See id. at xv-xvi; Dave Donnelly, Hawaii: A Bag with Grace, Honolulu STAR Bull., May 30, 2003, available at http://starbulletin.com/2003/05/30/features/donnelly.html; Dana Thomas, Luxury Forever, NEWSWEEK, Oct. 25, 2004, at 44 . Shortly thereafter, sales of the newly christened Kelly Bag soared. See Thomas, supra. This extensive research of the history of the "Kelly Bag" was conducted by Deb Cupples.

The litigation over the Kelly Bag concerns the special branch of trademark law dealing with trade dress. The analysis that follows in this Essay is equally applicable to both traditional trademark and trade dress law. For the special issues raised by trade dress, see Anne Theodore Briggs, Hung Out to Dry: Clothing Design Protection Pitfalls in United States Law, 24 HASTINGS COMM.\& ENT. L.J. 169 (2002), and Sarah J. Kaufman, Note, Trend Forecast: Imitation is a Legal Form of Flattery-Louis Vitton Malletier v. Dooney \& Bourke, Inc., 23 CARDOzo ARTs \& ENT. L.J. 531 (2005).

28. See Hermes, 50 F. Supp. $2 \mathrm{~d}$ at 226.

29. See Hermes Int'l v. Lederer De Paris Fifth Avenue, Inc. 219 F.3d 104, 108-09 (2d Cir. 2000); see also Payless Shoesource, Inc. v. Reebok Int'l Ltd., 998 F.2d 985, 989 (Fed. Cir. 1993); Polo Fashions, Inc. v. Craftex, Inc., 816 F.2d 145, 148 (4th Cir. 1987). 
passes it off to the public as the genuine article, thereby confusing the viewing public and achieving the status of owning the genuine article at a knockoff price." 30

Protection of status signaling may also explain the outcome of more recent legislation aimed at protecting trademark owners from dilution. The Federal Trademark Dilution Act, enacted in $1996,{ }^{31}$ applies to situations in which the capacity of a "famous mark" to identify and distinguish goods and services is lessened. ${ }^{32}$ The Act expressly eliminates the need to show that the use of the complained-of mark resulted in confusion or that there was competition between the two marks. ${ }^{33}$ Thus, an important element of the Act is its focus on the mark instead of on consumers. Generally, dilution occurs when an infringer takes action that may tarnish or blur the distinctiveness of the original mark. Blurring refers to the idea that the first mark may lose its association with a particular manufacturer. Tarnishing, on the other hand, refers to the possibility that the original mark will be seen as associated with products of a lesser quality. In the legislative history, the dilution examples offered were "DUPONT shoes, BUICK aspirin, and KODAK pianos." "34 In short, Buick does not compete with manufacturers of aspirin, and aspirin buyers are unlikely to believe that General Motors manufactures Buick aspirin. Nonetheless, the use of the mark begins a blurring process that endangers the distinctiveness of "Buick."

Prohibitions on dilution can protect status signaling opportunities, but it is not completely clear whether dilution expands on those protections

30. Hermes, 219 F.3d at 109. As implied in the quotation, one issue that arises when confusion is examined is the sophistication of the buyers. See generally Meaghan E. Goodwin, Note, Pricey Purchases and Classy Customers: Why Sophisticated Consumers Do Not Need the Protection of Trademark Laws, 12 J. INTELL. PROP. L. 255 (2004) (arguing that in unique situations where the goods at issue are very expensive and rare, the traditional test of consumer sophistication should trump the other factors in the likelihood of confusion analysis).

31. Federal Trademark Dilution Act of 1995, Pub. L. No. 104-98, 109 Stat. 985, 985-86 (1996) (codified as amended at 15 U.S.C. $\$ 1125(C)(1)(2006)$ ).

32. See Clarisa Long, Dilution, 106 ColuM. L. REv. 1029, 1030 \& n.12 (2006) (discussing judicial enforcement of dilution law).

33. See generally Mark A. Lemley, The Modern Lanham Act and the Death of Common Sense, 108 YALE L.J. 1687 (1999) (discussing how dilution does not require consumer confusion); Jacqueline R. Knapp, Note, The Federal Trademark Dilution Act: The Circuit Split Makes a Desperate Call to the Supreme Court for Uniformity, 19 GA. ST.U. L. REV. 853 (2003) (exploring "inconsistent court interpretations" of the Federal Trademark Dilution Act); Teresa Rangel, Comment, What's the Secret?-Proving Actual Harm in Trademark Dilution, 47 S. TEX. L. REV. 131 (2005) (exploring the elements of dilution). For a discussion of dilution and Lockean theory, see Kenneth L. Port, The "Unnatural" Expansion of Trademark Rights: Is a Federal Dilution Statute Necessary?, 85 TRADEMARK REP. 525, 561-64 (1995).

34. Moseley v. V Secret Catalogue, Inc., 537 U.S. 418, 431 (2003) (quoting H.R. REP. No. 104-374, at $3(1995))$. 
already available under modern trademark interpretations. First, a dilution claim requires proof of a famous mark. It may be that status signaling is unlikely to occur unless a mark is famous, but this is not certain. ${ }^{35}$ In particular, anti-dilution legislation may not support status signaling associated with niche markets. On the other hand, a dilution claim does not require a showing of actual confusion. In this sense, a dilution claim may be a more valuable tool for protecting status signaling. Of course, the importance of this depends on the difficulty of establishing confusion under a traditional trademark theory. ${ }^{36}$

Most problematic is the Act's definition of dilution. As noted, dilution occurs when the distinctiveness of the mark is blurred or tarnished. In the case of status signaling, although blurring can be an issue, in most instances the claim will be based on the possibility that the reputation of the original mark has been tarnished. It is not clear, however, that the definition of dilution under federal law extends to tarnishing. The Supreme Court in 2003 considered the Federal Trademark Dilution Act in Moseley v. V Secret Catalogue, Inc. ${ }^{37}$ and observed:

The District Court's decision in this case rested on the conclusion that the name of petitioners' store "tarnished" the reputation of respondents' mark, and the Court of Appeals relied on both "tarnishment" and "blurring" to support its affirmance. Petitioners have not disputed the relevance of tarnishment . . . presumably because that concept was prominent in litigation brought under state antidilution statutes and because it was mentioned in the legislative history. Whether it is actually embraced by the statutory text, however, is another matter. Indeed, the contrast between the state statutes, which expressly refer to both "injury to business reputation" and to "dilution of the distinctive quality of a trade name or trademark," and the federal statute which refers only to the latter, arguably supports a narrower reading of the FTDA. ${ }^{38}$

35. See generally Christopher R. Perry, Trademarks as Commodities: The "Famous" Roadblock to Applying Trademark Dilution Law in Cyberspace, 32 CONN. L. REV. 1127 (2000) (arguing that "courts have been liberal in bestowing 'famous' status").

36. For a recent study of the impact of anti-dilution law, see Long, supra note 32.

37. 537 U.S. 418 (2003).

38. Id. at 432 (citing Robert N. Klieger, Trademark Dilution: The Whittling Away of the Rational Basis for Trademark Protection, 58 U. PITT. L. REV. 789, 812-13 \& n.132 (1997)); see also Scott Fetzer Co. v. House of Vacuums, Inc., 381 F.3d 477, 489 n.8 (5th Cir. 2004) (noting that the Supreme Court left open the question of "whether the FTDA creates a cause of action for tarnishing" (citing Moseley, 537 U.S. at 432)).

In Moseley, the Supreme Court quoted the legislative history indicating that dilution extended to tarnishment. Moseley, 537 U.S. at 431. Since Moseley, legislation has been introduced to extend 
The critical question is what the eventual outcome will be as courts and perhaps the Supreme Court (again) consider whether tarnishing the senior mark is sufficient to establish dilution. A decision by the Court or Congress indicating that dilution clearly extends to tarnishing would make anti-dilution a powerful protector of status signaling. ${ }^{39}$

\section{The ECONOMICS OF STAtUS Signaling}

Economists have written extensively about the phenomenon of making purchases in order to signal one's status. ${ }^{40}$ The analysis typically starts with what are called "Veblen goods." Closely related are goods that have "snob appeal." The notion of a Veblen good stems from Thorstein Veblen's work, The Theory of the Leisure Class. ${ }^{41}$ Veblen stressed the need of individuals to demonstrate their status through "waste." Thus,

[f]rom [a] . . . survey of the growth of conspicuous leisure and consumption, it appears that the utility of both alike for the purposes of reputability lies in the element of waste that is common to both. In the one case it is a waste of time and effort, in the other it is a waste of goods. ${ }^{42}$

When it comes to dress, according to Veblen, "[i]t is especially the rule of the conspicuous waste of goods that finds expression in dress." ${ }^{.43}$ Veblen

dilution to tarnishment. See generally Anne E. Kennedy, Note, From Delusion to Dilution: Proposals to Improve Problematic Aspects of the Federal Trademark Dilution Act, 9 N.Y.U. J. LEGIS. \& PUB. POL'Y 399 (2006) (discussing how dilution jurisprudence addresses tarnishment).

39. See generally Glynn S. Lunney, Jr., Trademark Monopolies, 48 EMORY L.J. 367 (1999) (discussing how trademark expansion risks creating an incentive structure fundamentally at odds with social welfare).

40. See, e.g., ROBERT H. FRANK, LUXURY FEVER: WHY MONEY FAILS TO SATISFY IN AN ERA OF EXCESS (1999) [hereinafter FRANK, LUXURY FEVER] (exposing the waste of spending to signal wealth and status); ROBERT H. FRANK, CHOOSING THE RIGHT POND: HUMAN BEHAVIOR AND THE QUEST FOR STATUS (1985) [hereinafter FRANK, CHOOSING THE RIGHT POND] (exploring the consequences of people's concerns about their economic status); Basmann et al., supra note 5 (testing Veblen's theory of conspicuous consumption); Chao \& Schor, supra note 5 (providing an empirical test to differentiate between status-motivated and non-status-motivated consumer demand); Robert D. Congleton, Efficient Status Seeking: Externalities, and the Evolution of Status Games, 11 J. ECON. BEHAV. \& ORG. 175, 176-77 (1989); Eliakim Katz \& Uriel Spiegel, Negative Intergroup Externalities and Market Demand, 63 ECONOMICA 513, 513-14 (1996); Harvey Leibenstein, Bandwagon, Snob, and Veblen Effects in the Theory of Consumers' Demand, 64 Q.J. ECON. 183 (1950) (incorporating concept of conspicuous consumption into theory of consumer demand).

41. Thorstein Veblen, The Theory of the Leisure Class(Penguin Books 1994) (1899).

42. Id. at 85 .

43. Id. at $\mathbf{1 6 7 .}$ 
describes as "waste" the elements of goods that are beyond merely functional-elements designed to demonstrate wealth and status. ${ }^{44}$ The snob effect is somewhat different. A Veblen good is one that signals by virtue of the price paid. Snob effects, on the other hand, are not directly related to the price paid, but rather to the capacity of the good to signal that the buyer is "different."

\section{A. Veblen Effects}

The most important effort to present the idea of conspicuous consumption in a more theoretical model is that of Harvey Leibenstein. ${ }^{45}$ Two constructs seem to fit the suggestion, as already noted, that one of the attributes of a good may be its price. It is important to understand how unconventional an idea this is. From the perspective of nearly all economic theory, goods and services have certain utility-creating potential that is inherent in the goods. This potential does not change when price changes or when the good becomes more or less scarce. If the price of the good goes up, people buy less because other goods become relatively more attractive. ${ }^{46}$ This is reflected by a conventional downward sloping demand curve.

In contrast, Veblen and Leibenstein suggest that price may be a characteristic of the good itself and, as such, price itself can be a source of utility. If people want to display their wealth, they will actually derive more utility from the good the higher its price. Presumably, up to some point they are willing to pay more. In effect, the seller is selling a high price $^{47}$ or at least the ability to signal that one has paid a high price.

Leibenstein illustrated this phenomenon by beginning with a single demand curve like $\mathbf{d l}$ in Figure 1. The curve depicts the traditional demand for a product if there are no Veblen effects at work. In other words, individuals react only to the functional qualities of the product. In terms of the Kelly Bag, for example, functional qualities include its durability, security, and design. Design refers to the satisfaction derived by purchasers as a result of the appearance of the bag, but not as a result

44. See id. at 97-98. According to Veblen, the term "waste" "is not to be taken in an odious sense, as implying an illegitimate expenditure of human products or of human life. . . It is ... called 'waste' because this expenditure does not serve human life or human well-being on the whole, not because it is waste or misdirection of effort or expenditure as viewed from the standpoint of the individual consumer who chooses it." Id.

In today's world of economic analysis, the term "waste" would probably not be used. Anything that is the source of utility can hardly be "wasteful." Veblen himself understood this. See id. at 98.

45. See Leibenstein, supra note 40.

46. In addition, a price increase decreases the real income or buying power of the individual, which also leads to a reduction in quantity demanded.

47. See Leibenstein, supra note 40, at 189. 
of any message it conveys to others.

Now suppose the good begins to have non-functional appeal as the product becomes a means of signaling wealth. This could mean a separate demand curve for each price that others believe the buyer has paid. Liebenstein called this the "conspicuous price." ${ }^{\text {" }}$ For example, in Figure $1, \mathrm{~d} 1$ now would be the demand for Kelly Bags if buyers understood others to believe the buyers had paid $\$ 500$. On the other hand, if the signaled or "conspicuous price" were $\$ 1,000$, the demand might be $\mathrm{d} 2$. In short, at every actual price, people would be willing to buy more bags the higher the conspicuous price. At a conspicuous price of $\$ 1,500$, the demand might be d3.

\section{Figure 1}

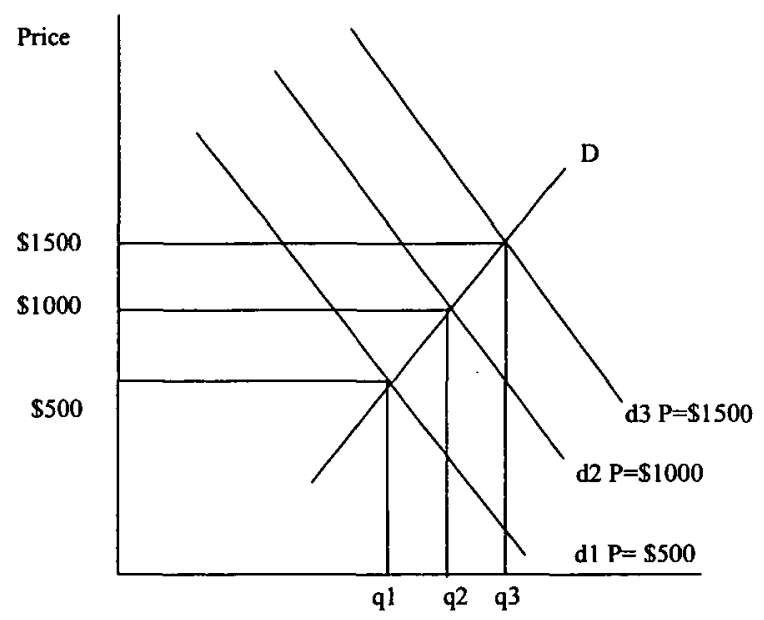

How does one determine the actual demand if demand shifts every time price changes? The answer is that in all likelihood, the actual price and the conspicuous price will eventually merge. ${ }^{49}$ That is, observers will eventually know the actual price and buyers will understand this. Thus, on $\mathrm{d} 1$, there is only one point that is relevant, and that is the point at which the

48. Leibenstein, supra note 40 , at 203.

49. See id. 
conspicuous consumption price and the actual price are the same. On the graph, this means quantity q1 would be demanded. The same analysis holds for $\mathrm{d} 2$ and $\mathrm{d} 3$. The only points that are relevant are those at which the actual and conspicuous consumption prices are equal. The quantities demanded will be $\mathrm{q} 2$ and $\mathrm{q} 3$, respectively. By connecting these points, one gets an upward-sloping demand curve, D. In effect, sellers are selling price, and the higher the price, the higher the quantity demanded. Obviously, the Veblen effect is just one effect and other effects may offset the upward-sloping demand curve depicted by $\mathrm{D}$ in Figure 1. In addition, as prices climb, the demand curve will likely take a normal downwardsloping shape as the good becomes too expensive. Similarly, at low prices the conventional downward slope will dominate because any Veblen effect will be minor or non-existent.

\section{B. Exclusivity Effects}

Closely related to the Veblen effect is what Leibenstein identified as the "snob effect." A true snob effect occurs when one's utility from a good is increased by the sense that one has different, and perhaps superior, tastes. ${ }^{50}$ It is not clear that Leibenstein's snob cares a great deal about whether others recognize this difference. In addition, it does not appear that the snob derives utility from the sense of relative deprivation that is generated by exclusivity. ${ }^{51}$

Leibenstein's analysis of snob effects is similar to that used to illustrate Veblen effects, and the model can be adapted to demonstrate the impact of exclusivity effects. Exclusivity signaling of the type protected by trademark law involves more than being different. It involves the recognition by others of that difference. The question is how demand reacts to the increased ability of a good to effectively signal to others that one is discriminating, special, privileged, or tasteful in comparison to others. Or, how does demand react to the ability of a good to generate utility from a sense of being relatively better off? The key is to purchase items others may want but cannot afford. For example, d1 in Figure 2 presents the demand of a good if the ratio of the number available to the

50. See Leibenstein, supra note 40 , at 189,199 . In a 1986 article cleverly entitled Counterfeit Goods, Richard Higgins and Paul Rubin analyzed the possibility that signaling was actually associated with the snob effect. Richard S. Higgins \& Paul H. Rubin, Counterfeit Goods, 29 J.L. \& ECON. 211, 213-14 (1986). Although Higgins and Rubin rely on Leibenstein's model, they apply it in a slightly different way. Leibenstein dealt with the impact of perceived "total market demand" on demand. See Leibenstein, supra note 40, at 199-200. Higgins and Rubin refer instead to the impact of "total number of units consumed" on demand. Higgins \& Rubin, supra, at 213-17.

51. See generally Jeffrey L. Harrison, Class, Personality, Contract, and Unconscionability, 35 WM. \& MARY L. REV. 445, 460-63 (1994) (discussing relative deprivation). 
number desired is a certain level. Here it shows the amount buyers are willing and able to buy at each price if they understood that, say, 1,500 units would be made available while 20,000 people find the good highly desirable. Again, the downward slope is dictated by the functional characteristics of the good. The demand curve $\mathrm{d} 2$ would represent demand if buyers expect that only 1,000 will be available, while $\mathrm{d} 3$ corresponds to a belief that 500 will be available. The curves shift outward (increase) because as the number of units expected to be sold as a percentage of the number desired decreases-i.e., the waiting list grows longer-the good becomes more valued as a signaling mechanism.

Again, the question is what actual demand is. If we assume that information will eventually be available about the number of units sold, then the only relevant point on $\mathrm{dl}$ is the one that corresponds with that level of output. The same is true for $\mathrm{d} 2$ and $\mathrm{d} 3$. By connecting these three points, the actual demand is derived, illustrated as D in Figure 2. The actual demand curve is steeper (more inelastic) than any of the individual curves. In effect, the quantity demanded increases more slowly along D as price decreases than it does with respect to any of the intermediate curves. This is because as price goes down and quantity demanded increases, the effect is offset as the good loses its relative privilege effect.

Figure 2

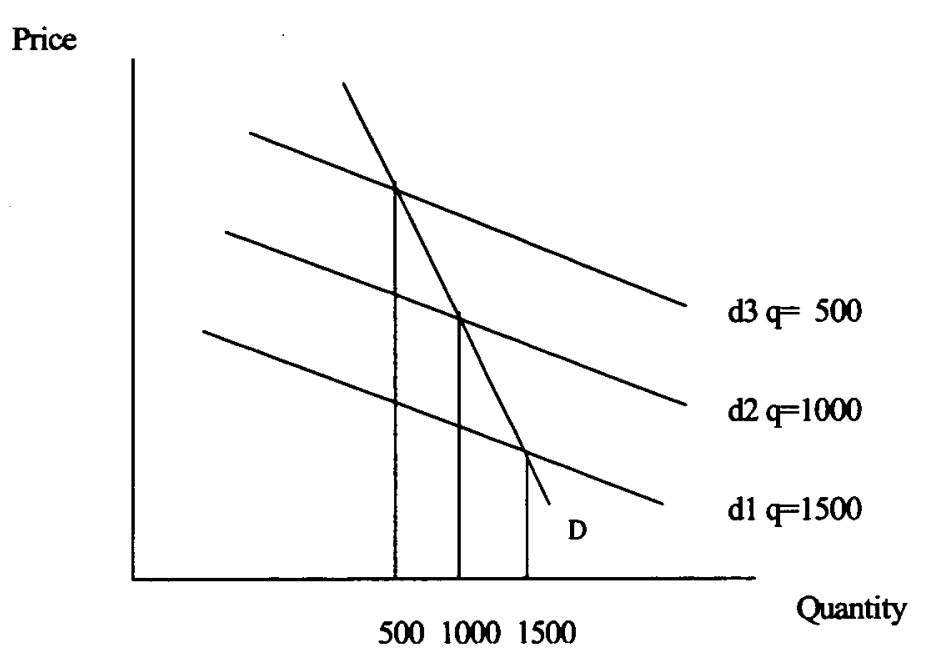

A very important feature setting snob or exclusivity signaling apart from the Veblen effect is the role of positional externalities. Economist 
Robert Frank captures the idea when he writes: "Most economists accept the proposition that market allocations may be suboptimal when production is accompanied by discharge of environmental pollutants. . . The dependence of utility on relative consumption gives rise to what $I$ have ... called positional externalities. Analytically, these externalities are no different from ordinary environmental pollutants." 52 In effect, status signaling of any kind can have a negative impact on others by eliciting feelings - envy, inadequacy, or annoyance-that are actually forms of disutility and which may be connected to physical and mental health. ${ }^{53}$ This is true with respect to both Veblen and snob effects. The difference is that the utility derived from snob effects may grow as the negative impact on others increases. In other words, there is an interdependency. ${ }^{54}$ As will be explained below, this raises both moral and practical problems that are specific to snob signaling.

\section{A Synthesis}

In the case of a Rolex watch or a Kelly Bag, which model fits best? Are buyers attracted because they want to be identified as part of an exclusive group or do they want to exhibit their wealth? In reality, probably both. While high prices and exclusivity are typically found together, the snob effect has a more direct associational element. That is, people want to be identified with exclusive groups. ${ }^{55}$ By contrast, a pure Veblen effect, as modeled by Leibenstein, is not as clearly related to the number of people excluded. The clearest common characteristics shared by the snob and Veblen effects are that both are unrelated to the functional or aesthetic appeal to the buyer, and both are dependent on the recognition by others of what the signals mean.

Both effects could be combined in a single model that cannot be presented in a two-dimensional space. The logic of such a model is, however, readily evident. Some goods can deliver on both motivations. They signal wealth and exclusivity. But this does not mean these effects

52. Robert H. Frank, The Frame of Reference as a Public Good, 107 ECON. J. 1832, 1843 (1997) (footnote omitted); see also Peter Townsend, The Meaning of Poverty, 13 BRIT. J. Soc. 210 (1962) (discussing poverty as a relative concept, one that cannot be defined without reference to outside factors). This possibility was not lost on Veblen, who wrote: "Since the consumption of these more excellent goods is an evidence of wealth, it becomes honorific; and conversely, the failure to consume in due quantity and quality becomes a mark of inferiority and demerit."VEBLEN, supra note 41 , at 74 .

53. See FRANK, LUXURY FEVER, supra note 40, at 140-45.

54. One could view the question like this: Would goods and services associated with snob effects be valued if the identities of buyers were kept secret and the goods were enjoyed only in private? Some value would remain but it is unlikely that all of it would.

55. See generally Kaushik Basu, A Theory of Association: Social Status, Prices and Markets, 41 OXFORD ECON. PAPERS 653 (1989) (exploring the role of association with a select group). 
will move in the same direction. For example, if there is a Veblen appeal and the price rises, the possible attraction of new buyers may result in lower snob appeal. A very expensive car might have a pronounced Veblen effect but begin to lose snob appeal as it increasingly becomes a favorite of the wealthy. The relative strength of the two effects as well as the impact of price on quantity demanded-ignoring all non-functional effects - determines the ultimate shape of the demand curve. ${ }^{56}$

The more important question in the context of this Essay is whether differences in the effects have public policy implications. Is it possible that there should be a public subsidy for efforts to communicate exclusivity but not for efforts to communicate wealth? Or, should public policy be designed to assist those who desire to communicate to others that they are wealthy but not to assist those for whom exclusivity is the important factor? Because these two effects are so closely intertwined, any effort to treat one would surely affect the other. Such a finely tuned policy is likely impractical.

\section{THE EFFICIENCY OF STATUS SignaLING}

On first impression, the idea that markets produce suboptimal amounts of information about status seems unlikely. Even less appealing for many is the idea that public policy should be used to subsidize that process. Specifically, why should the public be expected to support self-indulgence designed to enable people to appear to be superior to others when the entire process may be wasteful? For example, if there is competitive signaling with each person attempting to keep up with his or her relevant "Jones," a great deal may be expended but no one comes out ahead. Ultimately, the problem is similar to the prisoner's dilemma and is unlikely to be overcome by references to self-interest, narrowly defined. ${ }^{57}$ Still, unless one is willing to decide that the utility derived from status signaling is somehow different than the utility from other types of activities, there may be room to argue, as an economic matter, that subsidization is appropriate. ${ }^{58}$ The process of examining the possibility that public support for status signaling makes for good policy requires some initial considerations.

First, although it is probably impossible to design public policy to distinguish between Veblen effects and snob effects, it is useful to keep in mind the difference between the two. In its purest form, the Veblen buyer is not affected directly by how many others purchase the item as long as

56. See Leibenstein, supra note 40 , at 205-06.

57. See Frank, ChOOSING THE RIGHT POND, supra note 40, at 121-42 (1985); Viet D. Dinh, Forming and Reforming Wants, 85 GEO. L.J. 2121, 2128-32 (1997).

58. See, e.g., Kozinski, supra note 9, at 969-70. 
the signal about the price paid remains clear. ${ }^{59}$ Conversely, the snob effect depends on limited access regardless of price. In other words, the snob effect requires that others are both unable to possess the item and conscious of that deprivation. This difference is factored into the analysis that follows.

Second, in his original work, Veblen used the term "waste" to describe consumption designed to demonstrate one's wealth. The concern was that the market directed resources into the production of goods that were more whimsical than beneficial. ${ }^{60}$ The implication was not just that signaling should not be subsidized, but that spending on luxury items should be limited. This type of thinking is now out of fashion among economists because of the rise of the idea that one cannot make interpersonal comparisons of utility. As a purely economic matter, it is impossible to tell whether welfare is increased or decreased by the production of another Rolex watch as opposed to increased research on a cure for AIDS. Thus, by modern standards, the issue with respect to Veblen and snob effects must be assessed from a standpoint that accepts snob signaling as a source of well-being, at least for those doing the signaling.

A third consideration can be understood by reference to Judge Kozinski's analysis of the Veblen effect. ${ }^{61}$ In the context of the Rolex watch, Judge Kozinski asks whether it is economically beneficial to producers to sell Rolex copies. According to Judge Kozinski, allowing the copies to exist is "a pure loss" because it "will make it less likely that Rolex ... and others will invest in image advertising, denying the imageconscious among us something we hold near and dear. ${ }^{.62}$ Framing the issue this way leads to only one answer, but it is an odd perspective. Judge Kozinski's view suggests those who purchase Veblen or snob goods are entitled not to have their signaling made less effective by discontinuing public subsidization. A better question and one addressed here is whether the utility derived from Veblen and snob effects is worthy of public

59. Obviously, under most conditions, increased sales mean lower prices. A seller attempting to market a good for its Veblen qualities would presumably not attempt to sell so many that a price decrease would be required.

60. See also Stuart Chase, The Tragedy OF Waste 27, 30-31, 53, 85-90 (1925); Paul M. Gregory, $A$ Theory of Purposeful Obsolescence, 14 S. ECON. J. 24, 29, 39, $43-44$ (1947); Daniel Horowitz, Consumption and Its Discontents: Simon N. Patten, Thorstein Veblen, and George Gunton, 67 J. AM. HIS. 301, 309 (1980); Reginald Lennard, The Taxation of Luxury, 28 ECON. J. 287, 294 (1918).

61. See Kozinski, supra note 9, at 969-70. Professors Dogan and Lemley describe Judge Kozinski as discussing Veblen goods. See Stacey L. Dogan \& Mark A. Lemley, The Merchandising Right: Fragile Theory or Fait Accompli?, 54 EMORY L.J. 461, 492 (2005); Lemley, supra note 33, at $1706 \mathrm{n} .98$. In reality, Judge Kozinski expressed the idea as "[k]eeping the supply low and the price high." Kozinski, supra note 9, at 970.

62. Kozinski, supra note 9, at 970. 
expenditures.

Fourth, as an economic matter, efforts to subsidize either snob or wealth effects fail an economic test based on Paretian standards. ${ }^{63} \mathrm{~A}$ change in resource allocation is Pareto Superior if it leaves at least one person better off and no one worse off. It is a very rigid test that, in some respects, limits the role of government to practically nothing. In the case of Veblen and snob effects, using taxpayer funds to support the system instantly fails the Pareto test.

Fifth, the question of whether status signaling satisfies the less stringent Kaldor-Hicks or wealth maximization test ${ }^{64}$ raises a further concern. This test requires only that those benefitting from the reallocation of resources could compensate those who are worse off. It is important to note that "benefit" here refers to the net benefit resulting from government assistance in one form or another. Benefit is measured in terms of the value attributed to the gain. To understand why this approach can be a bit sticky, it is useful to examine it in the context of criminal law. Economists often address the issue of efficient levels of criminal activity or, more directly, the efficient level of activities that harm others. ${ }^{65}$ This idea can be applied to conduct ranging from double parking to car theft or assault. In the case of a car theft, for example, if the benefits of taking a car without permission-say, to take an injured person to the hospital-exceed the social cost of theft, it is efficient to do so. In fact, a case can be made that it is the possibility of efficient car theft that explains a decision not to set penalties high enough to deter all car theft. ${ }^{66}$

On the other hand, when the "benefit" of the crime is directly linked to the harm caused and the level of that harm, the analysis of efficiency is more difficult. For instance, suppose the benefit one gets is derived from the pain the victim seems to experience. ${ }^{67}$ As the pain increases, so does the benefit. There may still be an efficient level of assault but, as Richard Posner points out, the possibility that a wealth-maximizing analysis would permit the harmful activity is an indication of the weakness of the method

63. See JEFFREY L. HARRISON, LAW AND ECONOMICS: CASES, MATERIALS AND BEHAVIORAL PERSPECTIVES 50-51 (2002) (explaining the concepts of Pareto optimality and Pareto superiority).

64. See id. at 59-60.

65. See generally Gary S. Becker, Crime and Punishment: An Economic Approach, 76 J. PoL. ECON. 169 (1968) (exploring the efficient levels of resources and punishment that should be used to enforce different kinds of legislation).

66. Car theft may not be punished more severely than it is because, while we would like people not to steal cars for joy rides, it may be desirable to steal a car to take an injured person to the hospital or to escape a natural disaster.

67. In other words, the parties have interdependent utility functions. In the case of love or caring, one may be affected positively by the enjoyment of another. In the case of snob effects, one may be affected positively by the displeasure of others. 
of analysis ${ }^{68}$ In addition, there is something of a practical problem. It is relatively easy to compare the cost of having a car stolen to the benefits experienced by the thief because these two amounts are not dependent on each other. On the other hand, in the case of some crimes-like assault or rape-the analysis is dynamic: The benefit changes as a function of the harm caused, and the process of determining an efficient level, if any, is more elusive.

The same type of analysis ${ }^{69}$ and its limitations can be applied to snob signaling. ${ }^{70}$ To some extent, value and demand for snob signaling is linked to the deprivation of others. This is not to say there are not instances in which someone purchases a good or service that sets him or her apart and chooses to enjoy the good or service in private. In these cases, good feelings are not intensified by virtue of the recognition of the difference by others. In fact, there is no signaling at all. But when there is signaling, it is hard to completely separate the need to signal one's difference from the third party feelings of envy, unmet needs, injustice, frustration, and inadequacy. To the extent these feelings are positional externalities of snob displays and to the extent they enhance the pleasure of those making the displays, we begin to see the moral and the practical complexities of an economic analysis of crime.

\section{A. Veblen Effects}

A general evaluation of Veblen effects subsidization begins with the question of whether information about wealth would be produced in suboptimal amounts in the absence of public subsidization. As noted above, the Veblen effect is viewed as not depending on feelings of exclusivity per se. In order for subsidization to make economic sense, one must decide that wealth signaling has a public good quality. ${ }^{71}$ A close look at the question illustrates how bizarre a policy of subsidizing wealth

68. See Richard A. POSNER, ECONOMIC ANALYSIS OF LAW 216 (6th ed. 2003). Posner points out that the analysis can still determine an efficient level of crime-usually expressed in terms of efficient levels of rape- but the fact that the methodology may suggest this unthinkable result is indicative of "limitation[s] on the usefulness of that theory." Id.; see also Robert $\mathrm{H}$. Frank, Why Is Cost-Benefit Analysis So Controversial?, 29 J. LEGAL STUD. 913 (2000) (providing a defense of the cost-benefit principle, but also discussing the shortcomings of cost-benefit analysis); Richard A. Posner, The Ethics of Wealth Maximization: Reply to Malloy, 36 U. KAN. L. REV. 261, 263-65 (1988); Gary T. Schwartz, Economics, Wealth Distribution, and Justice, 1979 WIS. L. REV. 799, 802-04.

69. Clearly, however, an economic rationale for rape is a far more repugnant concept than one related to status signaling.

70. As presented here, the issue does not apply to Veblen effects. Although there may be positional externalities, they do not then lead to increased utility for the signalers.

71. The second question is whether the availability of the information at subsidized levels offsets the harmful effects. 
signaling seems. Public goods result in positive externalities and are subject to free-riding. Take for example, police protection, one of the usual examples of why free-riding might lead to suboptimal results. Each person desires security, but each person also realizes that if his or her neighbor buys a watch dog or pays to have someone patrol the streets, there will be an overflow of benefits. Consequently, there is a temptation to free-ride and enjoy the security provided by your neighbor. The problem is that if everyone behaves similarly, there will be no security, even though security is highly valued. In different terms, there is a demand for security, but it is not revealed in the market because each party desires to free-ride. Since the demand is not manifested, the actual production will be suboptimal.

The critical issue with respect to wealth signaling is whose demand is relevant. For example, is it the viewers of wealth information who understate their demand in hopes of free-riding on the efforts of others? Is it the signalers themselves who demand avenues for delivering their signal but understate that demand in hopes that others will provide it for them? Neither of these seems likely. The idea that the viewers of wealth signals are somehow involved in a strategic game of pretending they are not curious seems, on its face, improbable. Similarly, those engaged in wealth signaling are unlikely to understate their demand because a signal about one's wealth is personalized. More specifically, information about a person's wealth is - unlike public goods-exclusive. Unlike the barking watch dog and its benefits to the entire neighborhood, information about Bill Gates' wealth cannot benefit Warren Buffet.

The only possible public good rationale would have to be that some goods that signal wealth are "undersupplied" because investment in their production is not profitable. This would occur when demand for specific means of signaling is understated because potential buyers fear free-riding by, for example, counterfeiters. Notice that this is not an argument that wealth signaling is produced in suboptimal amounts. Instead, it is an argument that specific suppliers in the market are unable to compete effectively because they cannot limit the use of their means of communication. In other words, these producers are unable to offer-as a product characteristic - a promise of exclusivity to potential buyers.

Consequently, the judicial opinions that extend trademark protection to wealth signaling ${ }^{72}$ do not address the issue of suboptimal levels of information about wealth. Instead, these are decisions that protect producers from competition by other producers who can actually deliver exclusive wealth signaling. Wealth signals that permit no free-riding abound. Exclusive neighborhoods, expensive cars, extravagant vacations and parties, yachts, and cosmetic surgery are all effective wealth signals that are not subject to free-riding by counterfeiters and need no subsidy

72. See supra notes $22-30$ and accompanying text. 
from the government. In fact, those who protect their brand or appearance because they are selling signaling capacity do not need a comparable subsidy because they are simply competing with a variety of other suppliers of the same "product." 73

An analogy from antitrust law may help bring this point into focus. A plaintiff in an antitrust case lacks standing unless the harm suffered is antitrust injury ${ }^{74}$ Antitrust injury is the injury that results from a loss of competition. The plaintiff's interest and the public's interests (in more competitive markets) must be aligned for the plaintiff to have standing. For example, a firm does not have standing to challenge the merger of two of its competitors if the harm it seeks to avoid is simply the result of now having to compete with a firm that can deliver better goods at lower prices. ${ }^{75}$ In the case of wealth signaling, the issue is whether the interests of the public are aligned with that of signal sellers. Here the public interest is in maximizing the net total welfare derived from wealth signaling. The case has been made that this goal can be realized by relying on "natural"" signaling goods and services. Adding new competitors does not increase the amount of signaling bought and sold. Instead, the protection for artificial competitors in this market only adds to the number of firms that will divide up a finite amount of spending. In other words, it is a net loss to society. An expenditure designed exclusively to have distributive effects but lacking utility or wealth increasing effects is not wealth maximizing.

In short, it seems unlikely that those who demand wealth signaling actually demand less or that less is sold because some of the means of disseminating this information are ineffective without trademark protection. If, in fact, the "quantity" of wealth signaling bought and sold in markets remained constant without stretching trademark law to assist specific producers, the question then becomes whether it should be an element of public policy to subsidize relatively inefficient producers of wealth signaling. It may be that it is appropriate, but that position cannot be supported by reference to any concept of economic efficiency. The question really has only distributive implications: How should the benefits from the marketing of wealth signaling be divided up?

73. For a similar, although not identical, view based on another line of reasoning, see Goodwin, supra note 30.

74. E. ThOMAS SUllivan \& JEFFrey L. HaRRISON, UNDERSTANDING ANTITRUST AND ITS ECONOMIC IMPLICATIONS 51-56 (4th ed. 2003). For a good example illustrating the concept, see Todorov v. DCH Healthcare Authority, 921 F.2d 1438, $1449-51$ (11 th Cir. 1991).

75. See Brunswick Corp. v. Pueblo Bowl-O-Mat, Inc., 429 U.S. 477, 487-89 (1977).

76. "Natural" in this context means goods and services that effectively signal exclusivity without government protection from free-riding. 


\section{B. Exclusivity Effects}

As discussed above, there are differences between Veblen effects and snob effects. Veblen effects demonstrate wealth while snob effects are more closely related to signaling that one is different from and superior to others. Natural Veblen-effect goods can be snob goods and vice-versa, but this is not always the case. For example, ostentatious displays of wealth are often shunned by those who claim to be different by virtue of their good taste. The effectiveness of the exclusivity or snob effect relates directly to the exclusion of others, sometimes independent of the price paid.

The analysis of the snob effect is more complex than that of Veblen effects. This is directly related to the fact that the snob impact is not measured by the price of the good alone. Notions of difference and exclusivity suggest an interpersonal component. Obviously there is no snob appeal if the product is obtainable by all. There must be a frame of reference by which comparisons are made. ${ }^{77}$ Within limits, ${ }^{78}$ buyers presumably draw more satisfaction the greater the number of people excluded from a comparable purchase. If the process is to work, the buyer must sense that those excluded have unmet demands. Perhaps buyers can be deluded into believing this is true when it is not, but the impact is likely to be greater if it is widely known that some privileged people are included and others are not. For example, in 1990 the Hermès Kelly Bags started at $\$ 2,850$, with a nearly one-year waiting list for orders. ${ }^{79}$ By 2004 , the waiting list had been closed for three years so Hermès could catch up on backorders. ${ }^{80}$ Instances like these may generate little in the way of sympathy, but the essence of the snob effect is that the product delivers more in the way of snob-based utility the longer the waiting list or the higher the level of unmet demand. ${ }^{81}$

Further complications arise from the fact that there may be fewer "natural" 82 sources of snob effects than there are for Veblen effects.

77. See generally Robert Frank, Frames of Reference and the Quality of Life, 79 AM. ECON. REV. 80 (1989) (discussing "the critical role of context as a determinant of human satisfaction").

78. Snob effects are most likely associated with being part of an exclusive group. Put differently, if there were only a few units of a product available, it is not clear that it could have much snob appeal.

79. See Margot Hornblower, As Luxe as It Gets; The Bold Scion of Hermès Gives an Old World Firm Fresh Pizazz, Time, Aug. 6, 1990, at 52.

80. See Paula Rath, Luxury in Bag at Hermès, HoNOLuLu ADVERTISER, Sept. 15, 2004, at $1 \mathrm{E}$ (reporting that Hermès "asked women to wait just to be put on the waiting list").

81. In fact, a long waiting list may become longer as the snob appeal increases. This possibility is suggested by advertising campaigns stressing exclusivity.

82. See supra note 76 . 
Obviously, there are many goods and services that are naturally in short supply, but scarcity alone is not enough to assure a snob impact. For example, it may be that the snob effect of owning a moon rock is less than owning a luxury car of which only 1,000 are made per year. In addition, some goods in short supply that would seem to have snob appeal, like a limited edition artwork, may be vulnerable to copying. Moreover, it is possible that the most effective snob effects are generated by advertising. ${ }^{83}$ The point is that the key to an effective snob product may be to keep supply of counterfeit products low, which typically requires some level of government involvement.

As already noted, snob signaling fails a Pareto test of efficiency. It fails not simply because of the direct taxation required to fund the administrative necessities, but also because it requires investment in a process that means making some feel worse off as a result of not possessing the snob good.

Under the wealth maximization standard, the test is whether those benefitting from the subsidization could compensate those incurring losses or costs. There are three costs. First is the value of the disutility suffered by those at whom snob signaling is aimed. These are the positional externalities described by Robert Frank. ${ }^{84}$ Second is the cost to the public of policing counterfeit goods. This includes the actual costs of administering the system and the welfare losses to those who would have purchased and enjoyed cheaper substitutes. Finally, there is the loss to consumers who would purchase the genuine good in order to enjoy its functional characteristics but cannot once quantities are limited in order to increase the snob appeal. ${ }^{85}$

This third cost can be illustrated through the use of a graph. Figure 3 starts with the functional demand curve di, also depicted in Figure 2. In the graph, 1,000 units are sold at $\$ 10$ each. Consumer surplus is equal to the area of the triangle P1BC. ${ }^{86}$ This can be viewed as function-related consumer surplus because it is independent of status signaling and $\mathrm{dl}$ reflects functional demand only.

83. There is an obvious theme of exclusivity in a great deal of advertising.

84. See supra note 52 and accompanying text.

85. This is not the same as the total amount spent on goods that have snob appeal. Instead, the issue is how much a good's value is enhanced by snob appeal. Put differently, how much would the value of goods drop if it were exactly the same functionally but included no outward indication that it was limited in number?

86. Consumer surplus is the difference between what individuals are willing to pay and what they are required to pay for a good or service. The amount they are willing to pay is found on the demand curve at each level of output. 


\section{Figure 3}

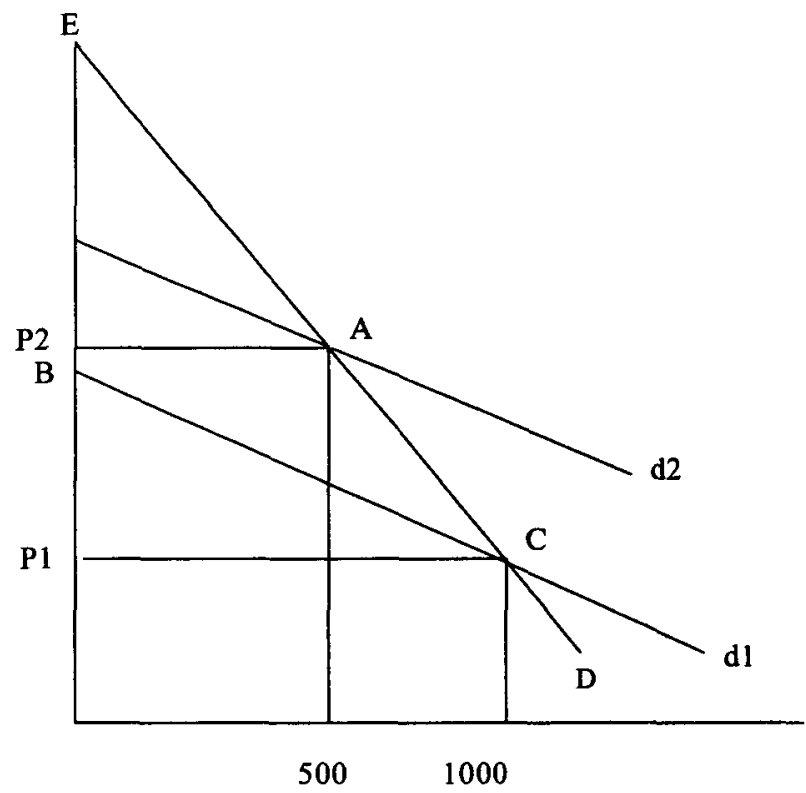

Now assume a snob appeal advertising campaign is successful. It stresses the limited availability of the item. As illustrated in Figure 3, demand will shift to $\mathrm{d} 2$, and curve $\mathrm{D}$ shows the curve allowing for snob effects. Output must be restricted. For the curve to maintain this new, more inelastic slope, the seller must retain its exclusivity. Thus, in Figure 3, sales are decreased to 500 . Consumer surplus is now equal to the area of P2AE. This can be viewed as the snob-related consumer surplus. The successful manufacturer of the snob good will be better off as a result of raising the price in a market in which demand has become inelastic ${ }^{87}$ On the other hand, the cost to consumers is the difference between the area of triangle $\mathrm{P} 1 \mathrm{CB}$ and the area of triangle $\mathrm{P} 2 \mathrm{AE}$. This is an empirical question, and the graph is drawn to suggest that the areas may be roughly the same. In reality, either triangle could be larger depending on the slopes of $d 1, d 2$, and D.

87. More technically, all demand curves have elastic and inelastic regions. When price is increased in the inelastic portion of the curve, total revenue increases and costs of production decline. The net impact is an increase in profit. The economic impact of increasing a good's snob appeal is to increase the inelasticity of demand, thus allowing for profit-increasing price increases. 
When the area of the snob effect consumer surplus is less than the functional consumer surplus (P2AE $<$ P1CB), there is no economic basis for subsidizing snob signaling. On the other hand, if the functional consumer surplus is less than the snob consumer surplus, a second step is required. The net increase in consumer surplus must be compared with the cost of policing counterfeit goods and the disutility associated with positional externalities. ${ }^{88}$

The outcome of this trade-off cannot be anticipated, but the analysis tracks the one found in the context of any study of negative externalities. In fact, the right to engage in snob signaling or to be free of it is comparable to the issue that arises when there are competing uses of resources more generally. ${ }^{89}$ There are two principle differences. First, those creating positional externalities, as opposed to the conventional externalities, are not indifferent to the level of the negative externality. As it grows, so may their gratification. Second, most analyses of externalities do not involve parties who must make out-of-pocket expenditures in order to produce the externality.

One could apply a Coasian perpective to the issue and view the right to exclude free-riders for the purpose of advancing snob signaling as a "right" desired by producers and purchasers of snob goods. The counterright is to be free from snob effects and the requirement that one assist in their subsidization..$^{90}$ On this side of the equation is the value people attribute to be free from snob displays and the direct costs described above. In a transaction-cost-free environment, regardless of how it is initially assigned, the right would be possessed by those attributing the higher value to the right. The empirical question is what would happen in a transaction-cost-free world, or if the right were subject to an auction in which there could be no free-riding.

Ultimately, it is impossible to completely discount a case for snob signal protection, but the case is weak. In some cases, the net consumer surplus may be positive. That is, the consumer surplus from snob signaling may be sufficiently positive to offset positional externalities and policing costs. At least intuitively, this seems unlikely. In addition, the only economic reasoning that would lead to this outcome is itself of questionable utility.

88. Suppose a widely distributed product with a great deal of functional appeal is converted to a snob appeal product. The decrease in units sold may be quite high. The outcome may be that the surplus enjoyed by those buying for functional purposes will exceed that experienced by snob customers.

89. See generally R. H. Coase, The Problem of Social Cost, 3 J.L. \& ECON. 1 (1960) (explaining market reactions to externalities).

90. These are distinct costs. One is the out-of-pocket cost of subsidization. The other is associated with positional externalities. 


\section{THE MORALITY OF STATUS Signaling}

In a 1993 article, Judge Kozinski discussed the "moral" dimension of status signaling and the protection of this dimension. He described "[m]oral claims" as those "based on the notion that people are entitled to something not as an incentive to work harder, but because it's right." ${ }^{.91}$ In other words, moral claims are non-instrumental. ${ }^{92}$ In this context, Judge Kozinski noted that the producers who have invested in creating an image of a product have a right to be protected from those who would free-ride on this image. Put differently, firms that invest in selling Veblen and snob signaling have a right to the profit from that investment and those who invest in this market have a right to government protection of that investment. ${ }^{93}$

Judge Kozinski's explanation, taken from a speech, is not fully developed. ${ }^{94}$ It consists of a reference to a Lockean theory of rights. Thus, "John Locke is credited with the observation that he who takes something out of a state of nature to create something useful thereby makes it his property. Given that our system of values embraces this view, the claim 'I've made it; it's mine,' has strong appeal."95 Of course, "appeal" to a majority of people does not a right make. Nor can rights be linked directly to the mere fact of investment. If so, income generated by investments in developing new methods of producing and delivering illicit drugs would similarly belong to drug dealers as a matter of right. Moreover, the idea that one who invests in the production of status signaling devices has a right to government investments to curtail free-riding may seem outlandish to some.

Nevertheless, Judge Kozinski's assertions raise an awkward and difficult problem. If one decides that those who invest in status-signaling products do not have a right to be protected from free-riding, how are they to be distinguished from the more typical property owner who has the right to exclude others from his or her property? What makes this question awkward is that trademark itself is a publicly created "right" and exists in this country only because it is a means to an end. In particular, someone attempting to protect this right would have to look outside the constitutional provision giving rise to intellectual property law. This is so

91. Kozinski, supra note 9, at 966-67.

92. Although typically discussed in the context of economics, utilitarianism is obviously also a moral philosophy. It does, however, have a strong instrumental component.

93. Unlike the economic analysis, the moral questions of Veblen and snob signaling do not appear to require separate examination.

94. This is not meant as a criticism of Judge Kozinski's powers of explanation. The article is a speech and evidently would not have been the appropriate place for a fuller discussion.

95. Kozinski, supra note 9, at 966 (footnote omitted). 
because it is uniformly agreed that the language, "[t]o promote the Progress of Science and useful Arts," are means to an end, and intellectual property law is based on incentives. ${ }^{97}$

Before returning to the possible Lockean argument for protecting status-signaling property, it is useful to examine two other possible justifications. One is based on Paretian standards. Although typically associated with economics, Paretianism has a strong moral component. ${ }^{98}$ In effect, the notion of rejecting resource allocations that leave anyone worse off would disallow using people to achieve the ends of others. This is consistent with Kant's Categorical Imperative. ${ }^{99}$ Thus, protection of status symbol sellers fails the Paretian economic test and, similarly, it fails any Kantian-based test.

A moral rights test similar to one premised on the Categorical Imperative is based on the writing of John Rawls. ${ }^{100}$ Rawls asks what the world would look like if the basic rules were determined while the eventual inhabitants of that world were behind the veil of ignorance. Behind the veil, participants would not know their relative positions with regard to intellect, talent, wealth, or anything else that would allow them to know in advance what rules would favor them when the veil is lifted. ${ }^{101}$ In effect, behind the veil, people can determine only the extent to which, if at all, they will allow themselves to be used as a means to the ends of others. The answer, according to Rawls, is not much. Rawls argued that two principles are likely to emerge:

First: each person is to have an equal right to the most extensive basic liberty compatible with a similar liberty for others. [Liberty Principle]

Second: social and economic inequalities are to be arranged so that they are both (a) reasonably expected to be to everyone's advantage, and (b) attached to positions and

96. U.S. CONST. art. I, § 8.

97. See Sony Corp. v. Universal City Studios, Inc., 464 U.S. 417, 429 (1984); Twentieth Century Music Corp. v. Aiken, 422 U.S. 151, 156 (1975); Mazer v. Stein, 347 U.S. 201, 219 (1954); United States v. Paramount Pictures, Inc., 334 U.S. 131, 158 (1948); Fox Film Corp. v. Doyal, 286 U.S. 123, 127-28 (1932).

98. It has been noted that that the Lockean theory of property is Paretian in nature. See David McGowan, Copyright Nonconsequentialism, 69 Mo. L. REV. 1, 38 (2004).

99. See IMMANUEL KaNT, Foundations Of THE METAPHYSICS OF MORALS AND What Is ENLIGHTMENT? 38 (Lewis White Beck trans., 2d ed. rev. 1990) (1785); see also JEFFRIE G. MURPHY, KANT: THE PHILOSOPHY OF RIGHT 57-65 (1970); Alan H. Goldman, Rights, Utilities and Contracts, in NEW ESSAYSONCONTRACT THEORY 131 (Kai Nielsen \& Roger A. Shiner eds., 1977); Mark Sagoff, At the Shrine of Our Lady of Fatima or Why Political Questions are Not All Economic, 23 ARIZ. L. REV. 1283, 1295-96 (1981).

100. See JOHN RAWLS, A THEORY OF JUSTICE (1971).

101. See id. at $136-42$. 
offices open to all. [Difference Principle] ${ }^{102}$

Perhaps as important as these two principles is Rawls's view that people, having determined the rules before knowing their affect by them, would experience a sense of justice when living under the rules. The impact of living in a society in which rules were viewed as fair would be, at least ideally, a reduction in levels of envy. ${ }^{103}$ This raises the question of whether a person who is relatively well-off in a Rawlsian world would be motivated to advertise that advantage. More directly, is there a demand for status signaling in a society that is not beset by envy? What this suggests is that while there may be a right to express one's material superiority, it may be pointless if others are indifferent to that signaling.

Still, the liberty principle suggests that those wishing to advertise status should be permitted to do so. This is a different question, however, from whether those in the original position-upon agreeing to inequality in some instances-would also agree to subsidize the advertisement of that inequality. In a social structure that begins from the ideal of equalitarianism, it is hard to see norms developing in which one expects a right to advertise the lack of equality whether through a system of trademark law or anything else. In addition, unless the regime used to support such a system were imposed only on the rich, the system would amount to a redistribution from the general population to those who are the most affluent. That is, snob signaling is likely to be engaged in by those who are most privileged and a generally-applied tax would affect all. This would violate Rawls's difference principle unless the process of redistribution eventually accrued to those worse off. This type of "contingent" right, however, is fully instrumental and does not fall into the category of a moral right. Note that this is no different from the issue of whether copyright or patent law would emerge in a Rawlsian world. Both of those possibilities might be consistent with the difference principle, in that allowing some people to profit from their compositions and inventions may ultimately accrue to the benefit of the least advantaged people. But again, there is no absolute right to have one's interest in intellectual property protected in a Rawlsian system.

As noted above, Judge Kozinski suggests that a moral right to subsidized status signaling can be supported by a theory of natural rights. He suggests, as many do, that one can link the exclusive right to intellectual property to Locke's more general justification for individual property rights. ${ }^{104}$ Locke's argument assumes that one takes resources

102. Id. at 60 .

103. See id. at 534-41.

104. See Kozinski, supra note 9, at 966 . Wendy Gordon has most succinctly expressed the Lockean case for intellectual property rights. See Wendy J. Gordon, A Property Right in Self- 
from a state of nature. The question is why, having taken something from the commons, one should be permitted to keep what has been taken. ${ }^{105}$ Starting from the moral right to one's labor, Locke argues that one who combines that labor with resources from the commons creates for himself a property right. ${ }^{106}$ In effect, the resource and the labor are inseparable, and to take the property is to take the labor. The Lockean argument may be even more powerful when applied to intellectual property. In the case of ordinary property, the moral issue is one of justifying removing something from the commons. The creativity of an individual, however, is hard to see as having been part of the commons in the first place. ${ }^{107}$ Thus, there would appear to be little need to justify claiming one's creativity as one's own.

There are complications with the application of Locke to intellectual property and, thus, to status signaling trademark generally. First, there is an element of indeterminacy. Unlike conventional property, intellectual property can be possessed by more than one person at a time. Thus, at least in matters of intellectual property, there must be an additional moral justification for being first. Unless there is moral significance to beating someone else to the punch, a Lockean approach to intellectual property seems to be an abstract concept that a property right should exist, but not an argument about who should actually possess that right.

Second, as has been pointed out, it is not clear why the person who applies labor to an element of the commons deserves the full value of the property as opposed to the value added by the labor. ${ }^{108}$ This is more of a problem when one applies Locke to intellectual property. Although it may be true that a creative person does not take from the commons in the ordinary sense, the fact is that no "new" idea comes until after a

Expression: Equality and Individualism in the Natural Law of Intellectual Property, 102 YALE L.J. 1533 (1993) [hereinafter Gordon, Property Right] (discussing Locke's influence on intellectual property law); see also Anupam Chander, The New, New Property, 81 TEX. L. REv. 715, 741-45 (2003); Wendy J. Gordon, Render Copyright unto Caesar: On Taking Incentives Seriously, 71 U. CHI. L. REv. 75, 78-87 (2004); McGowan, supra note 98, at 38; Adam D. Moore, $A$ Lockean Theory of Intellectual Property, 21 HAMLINE L. REV. 65, 66 (1997) (arguing for a "recast[ing] [of] institutions of intellectual property in a Lockean light"); Steven Wilf, Who Authors Trademarks?, 17 CARDozo ARTS \& ENT. L.J. 1, 24-32 (1999); Lior Zemer, The Making of a New Copyright Lockean, 29 HARV. J.L. \& PUB. POL'Y 891, 892-95 (2006) (“'A] comprehensive Lockean approach to copyright would provide significant recognition for the public role in the making of authorship and art.").

105. See John Locke, Two Treatises of Government 307 (Peter Laslett ed., Cambridge Univ. Press 1960) (1690).

106. See id. at 306.

107. See Richard A. Epstein, Liberty Versus Property? Cracks in the Foundations of Copyright Law, 42 SAN DIEGO L. REV. 1, 21 (2005); Lloyd L. Weinreb, Copyright for Functional Expression, 111 HARV. L. REV. 1149, 1222-24 (1998).

108. Robert Nozick makes the point that someone dumping a can of tomato juice in the ocean so that it spreads throughout the ocean would not be regarded as laying claim to the ocean. See NozicK, supra note 11, at 174-75. 
considerable amount of exposure to the ideas of others. Their ideas, no less than the ideas of the person making a claim to intellectual property, resulted from their labor. At best, if the final product is something worth protecting as property, it is not obvious why the inventor or creator is deserving of the full value when his or her labor may simply be the final touch. ${ }^{109}$ Of course, one may take the view that a vivid imagination cannot be equated with labor at all. If so, one must look beyond Locke to find a basis for the moral significance of being more imaginative than others (or more accurately, having an imagination that produces marketable results).

Third, if as Wendy Gordon suggests, "[a]imless effort is not labor,"110 and the discovery of new ideas is not the result of effort but of inspiration, does the recipient of that inspiration deserve property right protection? Or is the "creator" merely a conduit for whatever genetic gifts he or she enjoys? Finally, creating intellectual property is one thing, but profiting by virtue of market conditions is another. ${ }^{111}$ Market conditions, ultimately the critical element of what makes intellectual property valuable, are not likely to be the result of the property itself.

These arguments show that the connection between Locke and intellectual property is far from direct. Even more tenuous is the claim that the creation of trademarks for the purpose of status signaling can be reconciled with Lockean ideals. It bears remembering that the question is not whether one should have the right to communicate a product's maker or origin as a means of lowering consumer search costs, but whether the developer of a status signaling device-independent of protecting potential purchasers - should be afforded government protection of that right. There are a number of reasons why one might not make this jump. A better understanding follows from seeing Lockean justifications in a broader context. Locke wrote from the perspective that all men are moral equals with equal rights to share in the commons. The puzzle was under what circumstances individuals would be permitted to claim an exclusive right to some element of the commons. The overriding concern was not to harm others. ${ }^{112}$ Thus, for many, the Lockean question may have a simple answer. If one believes that status signaling is ultimately wasteful or harmful, then a moral right to property, the value of which is at least in part measured by the ability to unsettle others, is hard to reconcile with a Lockean ideal. If the data suggesting the harmfulness of social rankings are believed, then

109. See Edwin C. Hettinger, Justifying Intellectual Property, 18 PHIL. \& PUB. AFF. 31, 38 (1989).

110. Gordon, Property Right, supra note 104, at 1547.

111. See Hettinger, supra note 109, at 38-39; Mark P. McKenna, The Right of Publicity and Autonomous Self-Definition, 67 U. PITT. L. REV. 225, 254 (2005).

112. See LOCKE, supra note 105, at 309; see also Gordon, Property Right, supra note 104, at 1541-49. 
producing "property," the use of which is to advance the knowledge of social rankings, is also harmful. ${ }^{113}$

In addition, this signaling is inconsistent with at least the initial stages of government and the three limits on property identified by Locke. Thus, one may take only as much as can be used. Or as Locke wrote, property is limited to "[a]s much [1] and as a [m]an [t]ills, [p]lants, [i]mproves, [c]ultivates, and can use the [p]roduct of." 114 In addition, one must leave "enough, and as good ... for others." 115 Finally, one creates "private" property through labor. More generally, property was provided to the "[i]ndustrious and [r]ational," but "not to the [f] ancy or [c]ovetousness of the [q]uarrelsom and [c]ontentious." 116 Although an agreement to introduce money into society results in a relaxation of some of these standards, the respect for others implicit in these conditions stands in stark contrast to a system of government that has as one of its duties the facilitation of ostentatious behavior. ${ }^{117}$ Moreover, exclusivity with respect to any form of intellectual property is inconsistent with the idea of leaving "enough and as good." This is not to say that Locke did not recognize the imperfections of men, ${ }^{118}$ but this is a different matter than whether promotion of these imperfections should become a part of government policy.

Perhaps more importantly, Locke's view on property cannot be assessed without considering the government action needed to protect that policy. Locke's view of property begins with the sanctity of labor. It is through labor that one moves from the commons to private property. At the same time, the system of government required to protect those property rights is dependent on taxation, which involves the ability of the state to take part of one's labor. ${ }^{119}$ This results in a trade-off that Locke does not

113. See, e.g., RichaRd G. WILKInson, Unhealthy Societies: The Afflictions of INEQUALITY (1996) (suggesting that societies with "the smallest income differences between rich and poor" are the healthiest, and that "[i]nequality and relative poverty ... increase death rates"); M.G. Marmot et al., Health Inequalities Among British Civil Servants: The Whitehall II Study, 337 LANCET 1387 (1991), available at 1991 WLNR 2987034 (discussing "some possible reasons for the differences between social classes in disease incidence and health"); Richard G. Wilkinson, Income Distribution and Mortality: A 'Natural' Experiment, 12 SOC. HEALTH \& ILLNESS 391, 409 (1990) ("[I]t appears that health is . . . a psychosocially mediated function of the structure of inequality in society."). For a further discussion of these and others sources, see FRANK, LUXURY FEVER, supra note 40 , at $142-45$.

114. LOCKE, supra note 105, at 308 (emphasis omitted).

115. Id. at 306.

116. Id. at 309.

117. The use of money carries with it an implied consent that there can be accumulations of property and wealth. See id. at 319.

118. See id. at 329.

119. See id. at 380; Donna M. Byme, Locke, Property, and Progressive Taxes, 78 NEB. L. REv. 700, 703-05 (1999). 
address directly: Property is to be protected, but property must be taken in order to provide the protection. He notes that people create a community and become subordinate to the state in the interests of "their comfortable, safe, and peaceable living." 20 In addition, it seems clear that taxation and government action must be based on approval of the majority. Thus, even if status signaling were not harmful, it is doubtful that a Lockean system of taxation-with majority consent-would be employed to establish and protect a right to signal one's status or spending capacity. The idea that one acquires great wealth, trades it for goods and services, and then looks to the government to protect status signaling as matter of right seems very remote from the small role of government and limited property rights that Locke envisioned.

In the end, subsidized status signaling cannot be reconciled with any moral philosophy. Those philosophies that stress individual freedoms are unlikely to support government interference with expression regardless of the impact on others. The same values that favor limited government are very unlikely to support taking, through taxation, from some to subsidize those engaged in status-signaling speech or those who gain commercially by marketing status-signaling products.

Conversely, philosophies with a more egalitarian nature may be less resistant to taxation for purposes of redistribution or the provision of public goods. These types of interests, however, seem flatly inconsistent with a program of subsidizing those who wish to publicize their wealth and exclusivity at the literal expense of others.

\section{SUMMARY}

A relatively recent reinterpretation of trademark goes beyond assisting sellers and buyers by reducing information costs. Now trademark protects efforts to signal one's status to non-purchasers. This can be in the form of simply signaling wealth or signaling that one has specialized and presumably superior or more refined tastes. This process is not cost-free to the public. ${ }^{121}$ Thus, the question becomes whether there is an economic or moral justification for such subsidization.

The economic question centers around whether information about status has the character of a public good. In other words, is status information produced in suboptimal amounts without subsidization? In cases involving strict wealth signaling, this is almost certainly not the case.

120. LOCKE, supra note 105 , at 349 .

121. For an argument that once a trademark becomes a communicative symbol standing for something besides source or sponsorship, the public acquires an ownership interest in the communicative power of the trademark, see Malla Pollack, Your Image Is My Image: When Advertising Dedicates Trademarks to the Public Domain-With an Example from the Trademark Counterfeiting Act of 1984, 14 CARDOZO L. REV. 1391 (1993). 
Assuming there is a demand for this information or for the ability to transmit it whether or not anyone is listening, there are ample private market means of making the message clear. Government involvement simply distributes the profit from the sale of the product.

Exclusivity signaling is a more complicated matter. Economic theory suggests that a public good argument can be made. This would occur when the benefits from exclusivity signaling exceed a number of costs, including those associated with positional externalities. Although this seems unlikely, the possibility exists. An important caveat is in order when applying economics to exclusivity signaling. To the extent that the utility of those signaling and selling signaling products is dependent on the level of positional externalities, it is not clear that economic analysis is appropriate.

Aside from economic questions, there is the question of whether public subsidization can be morally justified. Here the concept of "moral justification" means something other than a cost/benefit analysis. The writings of John Locke are commonly used to defend private property rights. Locke's theory views the creation of property rights as a result of applying one's labor to the commons. It is difficult to apply his theory to intellectual property and especially to trademarks that are used to signal wealth or exclusivity. For example, it is not clear that intellectual property originates from the commons, nor is it clear what it means to apply one's labor to these "commons." Finally, the notion of taking property by virtue of a tax system in order to assist in the maintenance of property, the value of which may depend on positional externalities, seems remote for a Lockean system of government.

The movement of trademark law into the area of interpersonal signaling about status cannot be supported by notions of efficiency nor by appeals to moral rights consistent with either Rawlsian or Lockean theory. In addition, the use of trademark for status signaling is a necessary result of statutory interpretation. The reason for the cross-over of trademark from a method of lowering transaction costs to a legal means of protecting status signaling akin to tattoos and piercings for the relatively well-to-do is not clear. It is a judicially created "right" that seems to serve little more than the vanity of some at the expense of many more. 
